\title{
PENGARUH MOTIVASI BELAJAR, MINAT BELAJAR, DAN PERHATIAN ORANG TUA TERHADAP PRESTASI BELAJAR AKUNTANSI SISWA KELAS XI IPS SMA NEGERI 1 PRAMBANAN KLATEN TAHUN AJARAN 2016/2017
}

\author{
THE EFFECT OF LEARNING MOTIVATION, LEARNING INTEREST, AND \\ PARENTS' ATTENTION ON THE ACCOUNTING LEARNING ACHIEVEMENT OF \\ STUDENTS OF GRADE XI OF SOCIAL STUDIES OF SMA NEGERI 1 PRAMBANAN \\ KLATEN IN THE 2016/2017 ACADEMIC YEAR
}

\author{
Oleh: \\ Muhammad Aris Priyono \\ Pendidikan Akuntansi Universitas Negeri Yogyakarta \\ Muhammadaris95.ma@gmail.com
}

\section{Amanita Novi Yushita}

Staf Pengajar Jurusan Pendidikan Akuntansi Universitas Negeri Yogyakarta

\begin{abstract}
Abstrak
Penelitian ini bertujuan untuk mengetahui pengaruh Motivasi Belajar, Minat Belajar, dan Perhatian Orang Tua terhadap Prestasi Belajar Akuntansi Siswa Kelas XI IPS SMA Negeri 1 Prambanan Klaten Tahun Ajaran 2016/2017. Penelitian ini merupakan penelitian ex-post facto. Populasi penelitian ini adalah siswa kelas XI IPS SMA Negeri 1 Prambanan Klaten Tahun Ajaran 2016/2017 sejumlah 92 siswa. Instrumen penelitian menggunakan kuesioner dan pedoman wawancara. Kuesioner diuji validitas dan reliabilitasnya sebelum dilakukan pengumpulan data penelitian. Uji prasyarat analisis meliputi uji linieritas dan uji multikolinieritas. Uji hipotesis terdiri dari regresi sederhana, regresi ganda, sumbangan relatif, dan sumbangan efektif. Hasil penelitian: 1) Terdapat pengaruh positif Motivasi Belajar terhadap Prestasi Belajar Akuntansi dengan $r_{x 1 y}=0,874, t_{\text {tabel }}=1,987, r^{2}{ }_{x 1 y}=0,764$. 2) Terdapat pengaruh positif Minat Belajar terhadap Prestasi Belajar Akuntansi dengan $r_{x 2 y}=0,628, t_{\text {tabel }}=1,987, r^{2}{ }_{x 2 y}=0,394.3$ ) Terdapat pengaruh positif Perhatian Orang Tua terhadap Prestasi Belajar Akuntansi dengan $r_{x 3 y}=0,437$, $\left.\mathrm{t}_{\text {tabel }}=1,987, \mathrm{r}^{2} \times 3 \mathrm{y}=0,191.4\right)$ Terdapat pengaruh positif Motivasi Belajar, Minat Belajar, dan Perhatian Orang Tua secara bersama-sama terhadap Prestasi Belajar Akuntansi dengan $R_{y(1,2,3)=} 0,896, R_{y(1,2,3)}^{2}=$ $0,804, F_{\text {hitung }}=120,095, F_{\text {tabel }}=2,47$. Sumbangan Relatif Motivasi Belajar sebesar $60,81 \%$ dan Sumbangan Efektif 48,90\%. Sumbangan Relatif Minat Belajar sebesar 25,15\% dan Sumbangan Efektif 20,22\%. Sumbangan Relatif Perhatian Orang Tua sebesar 14,04\% dan Sumbangan Efektif 11,29\%.
\end{abstract}

Kata Kunci: Motivasi Belajar, Minat Belajar, Perhatian Orang Tua, Prestasi Belajar Akuntansi

\begin{abstract}
This research aims to know the effect of Learning Motivation, Learning Interest, and Parents' Attention on their Accounting Learning Achievement of students of Grade XI of Social Studies of SMA Negeri 1 Prambanan Klaten in the 2016/2017 Academic Year. The research was ex-post facto. The research population comprised students of Grade XI of Social Studies of SMA Negeri 1 Prambanan, Klaten, in the 2016/2017 academic year with a total of 92 students. Instrument research using questionnaire and interview guidelines. The questionnaire was assessed in terms of its validity and reliability before it was used to collect research data. The tests of analysis assumptions were tests of linearity and multicollinearity. The hypothesis testing used simple regression, multiple regression, relative contribution, and effective contribution. The results of the study showed that: 1) there was a positive effect of the learning motivation on the accounting learning achievement with $r_{x l y}=0.874, t_{\text {table }}$ $=1.987$, and $\left.r_{x y y}^{2}=0.764 ; 2\right)$ there was a positive effect of the learning interest on the accounting learning achievement with $r_{x 2 y}=0,628, t_{\text {table }}=1.987$, and $\left.r_{x 2 y}^{2}=0,394 ; 3\right)$ there was a positive effect of
\end{abstract}


parents' attention on the accounting learning achievement with $r_{x 3 y}=0,437, t_{\text {table }}=1.987$, and $r_{x 3 y}^{2}=$ 0.191; and 4) there were positive effects of the learning motivation, learning interest, and parents' attention as an aggregate on the accounting learning achievement with $R_{y(1,2,3)}=0,896, R_{y(1,2,3)}^{2}=0,804$, $F_{\text {observed }}=120,095$, and $F_{\text {table }}=2,47$. The relative contribution of the learning motivation was $60,81 \%$ and its effective contribution was $48,90 \%$. The relative contribution of the learning interest was $25,15 \%$ and its effective contribution was $20,22 \%$. The relative contribution of parents' attention was $14,04 \%$ and its effective contribution was 11,29\%.

Keywords: Learning Motivation, Learning Interest, Parents'Attention, Accounting Achievement.

\section{PENDAHULUAN}

Pendidikan merupakan sarana dan ujung tombak dalam pembentukan sumber daya manusia yang berkualitas, unggul, berakhlak, dan disiplin yang mampu bersaing dengan negara lain dalam berbagai bidang ilmu pengetahuan dan teknologi. Pendidikan yang berkualitas akan menyebabkan suatu bangsa dapat mencapai kemajuan di berbagai bidang. Penyelenggaraan pendidikan secara umum dapat dilakukan melalui beberapa cara yaitu melalui pendidikan non formal, pendidikan formal, dan pendidikan informal. Pendidikan informal adalah pendidikan keluarga. Pendidikan formal adalah jalur pendidikan yang terstruktur dan berjenjang yang terdiri atas pendidikan dasar, pendidikan menengah dan pendidikan tinggi. Pendidikan non formal adalah jalur pendidikan di luar pendidikan formal yang dapat dilaksanakan secara terstruktur dan berjenjang, dilaksanakan bagi warga masyarakat yang memerlukan layanan pendidikan yang berfungsi sebagai pengganti, penambah atau pelengkap. Pendidikan formal dalam rangka mendukung pendidikan sepanjang hayat. Oleh karena itu, melalui pendidikan inilah diharapkan dapat mengembangkan potensi dan tercapainya sumber daya manusia yang berkualitas tinggi. Salah satu bukti bermutunya pendidikan adalah dengan adanya prestasi belajar siswa, dimana prestasi belajar harus mengalami suatu peningkatan tidak hanya dalam satu mata pelajaran tapi semua mata pelajaran. Akuntansi merupakan salah satu mata pelajaran yang harus ditempuh oleh siswa SMA jurusan IPS dan siswa dituntut untuk memahami konsep, pengertian dan implikasi Akuntansi serta mampu untuk membuat pembukuan.

Secara psikologis, belajar merupakan suatu proses perubahan yaitu perubahan tingkah laku sebagai hasil dan interaksi dengan lingkungannya dalam memenuhi kebutuhan hidupnya. Prestasi belajar merupakan hal yang tidak dapat dipisahkan dari kegiatan belajar, karena kegiatan belajar merupakan proses belajar, sedangkan prestasi merupakan hasil dari proses belajar.

Prestasi Belajar Akuntansi dapat dinilai dengan matematis (angka) yang mencerminkan tingkat pemahaman siswa terhadap mata pelajaran Akuntansi. Pada umumnya, Prestasi Belajar Akuntansi yang ditunjukkan dalam angka-angka tersebut merupakan hasil penilaian melalui tes, ujian, maupun tugas dari guru. Prestasi Belajar Akuntansi yang diperolah siswa dalam periode tertentu akan dimasukkan dalam rapor.

Prestasi belajar merupakan hasil usaha yang telah dicapai seseorang setelah ia melakukan kegiatan belajar. Berdasarkan Permendikbud Th.2016 No.023 terkait Kriteria Ketuntasan Minimal (KKM) siswa, disebutkan bahwa standar keberhasilan belajar siswa dikatakan baik jika setiap siswa telah mencapai KKM yang sudah ditetapkan oleh sekolah dan jika belum mencapai KKM siswa wajib melakukan remidial. Oleh karena itu, berdasarkan acuan tersebut SMA Negeri 1 Prambanan Klaten menetapkan standar keberhasilan belajar $100 \%$ tanpa remidial dengan nilai KKM sebesar 75, standar tersebut berlaku juga untuk mata pelajaran Akuntansi. Akan tetapi, berdasarkan informasi data prestasi 
belajar pada mata pelajaran Akuntansi siswa kelas XI IPS SMA Negeri 1 Prambanan Klaten nilai Ulangan Harian (UH) sebelum remidial, nilai Ujian Tengah Semester (UTS) sebelum remidial, dan Ujian Akhir Semester (UAS) sebelum remidial diketahui bahwa siswa yang dapat menuntaskan nilai diatas Kriteria Ketuntasan Minimal (KKM) yang telah ditetapkan yaitu sebesar 75, hanya sebanyak 52 siswa $(56,52 \%)$, sisanya sebanyak 40 siswa $(43,48 \%)$ belum dapat mencapai KKM.

Penentuan Kriteria Ketuntasan Minimal (KKM) didasarkan pada Peraturan Pemerintah Nomor 19 Tahun 2005 tentang Standar Nasional Pendidikan (SNP) yang meliputi standar isi, standar kompetensi lulusan, standar pendidik dan tenaga kependidikan, standar sarana prasarana, standar pengelolaan, standar pembiayaan, dan standar penilaian pendidikan. Berdasarkan Peraturan Pemerintah Nomor 19 Tahun 2005 Kriteria Ketuntasan Minimal (KKM) ditetapkan oleh satuan pendidikan yang merupakan hasil musyawarah guru mata pelajaran di satuan pendidikan atau beberapa satuan pendidikan yang memiliki karakteristik yang hampir sama. Pertimbangan pendidik atau forum MGMP secara akademis menjadi pertimbangan utama penetapan KKM. Kriteria ketuntasan menunjukkan persentase tingkat pencapaian kompetensi sehingga dinyatakan dengan angka maksimal 100 (seratus). Angka maksimal 100 merupakan kriteria ketuntasan ideal. Target ketuntasan secara nasional diharapkan mencapai minimal 75.

Secara garis besar Prestasi Belajar Akuntansi dapat disebabkan oleh dua faktor yaitu (1) faktor internal (faktor dari dalam diri siswa), meliputi: indra pendengar, indra penglihat, intelegensi siswa, sikap siswa, bakat siswa, minat, dan motivasi. (2) faktor eksternal (faktor dari luar siswa), meliputi: keluarga, guru, masyarakat, Perhatian Orang Tua dan teman.

Motivasi Belajar dan Minat Belajar merupakan faktor internal dan Perhatian Orang Tua sebagai faktor eksternal.
Motivasi Belajar dan Minat Belajar sebagai faktor internal merupakan diduga menjadi penyebab belum optimalnya Prestasi Belajar Akuntansi siswa kelas XI IPS di SMA Negeri 1 Prambanan Klaten Tahun Ajaran 2016/2017. Maka dari itu, peneliti tertarik dan ingin melakukan penelitian terhadap masalah Motivasi Belajar dan Minat Belajar Akuntansi yang ada di kelas XI IPS tersebut. Selain Motivasi Belajar dan Minat Belajar, Perhatian Orang Tua juga menjadi salah satu faktor eksternal yang dapat mempengaruhi Prestasi Belajar Akuntansi siswa. Perhatian Orang Tua turut menentukan Prestasi Belajar Akuntansi karena merupakan salah satu faktor eksternal dalam mencapai Prestasi Belajar Akuntansi yaitu dilihat dari peran orang tua dalam menunjang pendidikan anak, salah satunya dengan cara memberikan perhatian. Adanya perhatian dari orang tuanya akan membuat anak termotivasi untuk berprestasi dibandingkan dengan anak yang kurang mendapatkan perhatian. Faktor-fakor yang mempengaruhi prestasi belajar tersebut merupakan masalah yang ditemukan pada siswa kelas XI IPS di SMA Negeri 1 Prambanan Klaten Tahun Ajaran 2016/2017 yang diduga menjadi penyebab belum tercapainya Prestasi Belajar Akuntansi siswa secara optimal.

Motivasi merupakan salah satu faktor yang turut menentukan efektif tidaknya proses belajar mengajar. Seorang siswa yang memiliki Motivasi Belajar mempunyai dorongan untuk melakukan suatu aktivitas sehingga tercapai tujuan yang diharapkannya, termasuk dalam belajar. Akan tetapi, berdasarkan hasil observasi yang dilaksanakan di kelas XI IPS SMA Negeri 1 Prambanan Klaten menunjukkan bahwa Motivasi Belajar siswa masih rendah. Hal ini ditunjukkan hanya 60 dari 92 siswa atau $65,21 \%$ siswa yang tidak tekun menghadapi tugas, dan dalam tugas kelompok ada siswa yang tidak senang memecahkan masalah soal-soal, serta masih ada siswa yang tidak bekerja mandiri. Sikap siswa seperti ini disebabkan setiap siswa merasa bahwa pelajaran Akuntansi sulit 
untuk dipahami sehingga Motivasi Belajar yang ada pada diri siswa masih rendah sehingga menyebabkan Prestasi Belajar Akuntansi belum optimal.

Minat Belajar juga merupakan salah satu faktor yang dapat menentukan Prestasi Belajar Akuntansi karena belajar dengan minat mendorong siswa belajar lebih baik daripada belajar tanpa minat. Minat memiliki peranan yang sangat penting dalam mempengaruhi kehidupan seseorang. Pengaruh minat mempunyai dampak yang besar terhadap perilaku dan sikap hidup individu dalam kehidupan sehari-hari. Dengan adanya Minat Belajar, siswa cenderung memberikan perhatian yang lebih besar dan mudah untuk memusatkan konsentrasi serta perhatiannya pada saat proses pembelajaran berlangsung sehingga rasa keinginan untuk mempelajari mata pelajaran akan tinggi.

Namun pada kenyataannya Minat Belajar siswa kelas XI IPS SMA Negeri 1 Prambanan Klaten belum optimal sehingga materi pelajaran yang diserap belum sampai pada titik maksimal. Hal ini ditunjukkan $70,65 \%$ atau 65 dari 92 siswa berpendapat bahwa akuntansi adalah pelajaran yang sulit, serta terlihat dari masih rendahnya keinginan siswa belajar akuntansi, masih adanya siswa yang bersikap acuh dan tidak mendengarkan ketika pelajaran sedang berlangsung, kurangnya keaktifan siswa pada saat tanya jawab dan ketika diberikan soal, dan ketika guru menjelaskan materi pelajaran masih terdapat siswa yang menyibukkan diri dengan kegiatan lain selain kegiatan belajar Akuntansi. Sikap tersebut akan berdampak pada rendahnya nilai-nilai tugas, ulangan harian, ujian tengah semester, maupun ujian akhir semester, yang kemudian akan berimbas pada rendahnya Prestasi Belajar Akuntansi.

Faktor lain yang turut menentukan Prestasi Belajar Akuntansi adalah Perhatian Orang Tua. Perhatian Orang Tua dalam mendidik anak di lingkungan keluarga sangat penting karena lingkungan keluarga adalah tempat terbaik dalam pembelajaran diri anak. Perhatian Orang Tua tercermin dari adanya bantuan yang diberikan orang tua kepada anak ketika anak mengalami kesulitan belajar, disaat anak tidak memiliki semangat, disinilah peran orang tua untuk memberikan perhatian berupa dorongan dan semangat.

Perhatian Orang Tua kepada anakanaknya dapat diwujudkan dalam penyediaan fasilitas pembelajaran yang dibutuhkan anak guna mendukung proses belajar siswa, kasih sayang orang tua, tanggung jawab sosial, memelihara dan membesarkan anaknya dan memberikan pendidikan, sehingga orang tua tidak akan bersikap masa bodoh tetapi justru akan menjalankan kewajibannya dengan penuh perhatian. Oleh karena itu, orang tua harus mendidik anak-anaknya dari kecil dan melihat perkembangan pendidikan anaknya, tetapi kenyataannya menunjukkan bahwa masih banyak orang tua yang belum memperhatikan pendidikan anaknya secara optimal. Dibuktikan berdasarkan hasil wawancara yang dilakukan secara acak pada 30 siswa kelas XI IPS di SMA Negeri 1 Prambanan Klaten menunjukkan bahwa 13 dari 30 siswa atau $43,33 \%$ siswa tidak diberikan kebebasan oleh orang tua untuk menentukan jadwal belajar, 26 dari 30 siswa atau $86,67 \%$ siswa tidak didampingi orang tua ketika belajar, 18 dari 30 siswa atau $60 \%$ siswa orang tuanya tidak mengetahui kesulitan belajar yang sedang dihadapi, 8 dari 30 siswa atau $26,67 \%$ siswa orang tuanya tidak memberikan solusi atas kesulitan belajar yang dihadapinya, 9 dari 30 siswa atau $30 \%$ siswa tidak mendapatkan motivasi dari orang tuanya ketika sedang tidak semangat belajar, 10 dari 30 siswa atau $33,33 \%$ siswa orang tuanya tidak memberikan penghargaan apapun ketika anaknya mendapatkan nilai ulangan atau nilai raport baik, 15 dari 30 siswa atau 50\% siswa orang tuanya tidak peduli ketika anaknya mendapatkan nilai ulangan atau nilai raport jelek, 4 dari 30 siswa atau $13,33 \%$ siswa yang diceritakan ketekunan dan keberhasilan belajar dari orang tuanya, 4 
dari 30 siswa atau $13,33 \%$ siswa yang tidak mendapatkan nasihat dari orang tuanya untuk belajar dengan baik, 13 dari 30 siswa atau $43,33 \%$ siswa orang tuanya tidak peduli ketika mereka tidak belajar. Berdasarkan data hasil wawancara tersebut, maka dapat disimpulkan bahwa Perhatian Orang Tua terhadap siswa kelas XI IPS masih tergolong rendah. Adanya perhatian yang diberikan orang tua kepada anaknya diharapkan akan berdampak pada pencapaian Prestasi Belajar Akuntansi di sekolah.

Perhatian Orang Tua kepada anakanaknya dapat dilakukan untuk meningkatkan semangat belajar anaknya guna mencapai Prestasi Belajar Akuntansi yang optimal dengan cara: (1) Memberi kebebasan/bersikap demokratis,

Memberi penghargaan atau hukuman, (3) Memberi contoh/bimbingan kepada anak, (4) Membantu kesuliltan belajar anak. Adanya perhatian yang diberikan orang tua kepada anaknya diharapkan akan berdampak pada pencapaian Prestasi Belajar Akuntansi di sekolah. Prestasi Belajar Akuntansi siswa yang mendapatkan Perhatian Orang Tua lebih baik dibandingkan dengan Prestasi Belajar Akuntansi siswa yang kurang mendapat Perhatian Orang Tua.

Dari uraian masalah di atas, peneliti tertarik untuk mengadakan penelitian tentang "Pengaruh Motivasi Belajar, Minat Belajar, dan Perhatian Orang Tua terhadap Prestasi Belajar Akuntansi Siswa Kelas XI IPS SMA Negeri 1 Prambanan Klaten Tahun Ajaran 2016/2017”.

\section{METODE PENELITIAN \\ Desain Penelitian}

Penelitian ini merupakan Penelitian ini merupakan Penelitian Ex-Post Facto, yaitu penelitian yang dilakukan atas peristiwa yang telah terjadi untuk mengungkapkan data yang ada atau menggambarkan variabel-variabel penelitian tanpa memberikan perlakuan atau manipulasi terhadap subjek yang diteliti. Sesuai dengan tujuan penelitian yang ingin dicapai yaitu untuk mengetahui pengaruh Motivasi
Belajar, Minat Belajar, dan Perhatian Orang Tua terhadap Prestasi Belajar siswa di SMA Negeri 1 Prambanan Klaten, peneliti menggunakan pendekatan kuantitatif. Peneliti mengumpukan data kuantitatif berdasarkan indikator dan variabel yang berhubungan dengan masalah yang akan diteliti, kemudian data kuantitatif tersebut dianalisis, dan dari hasil analisis tersebut peneliti berusaha menggambarkan keadaan sebenarnya.

\section{Tempat dan Waktu Penelitian}

Penelitian ini dilaksanakan di kelas XI IPS SMA Negeri 1 Prambanan Klaten yang beralamat di Jalan Manisrenggo KM 2.5 Prambanan Klaten. Penelitian ini dilaksanakan pada bulan Maret-April 2017.

\section{Subjek Penelitian}

Subjek penelitian ini berupa populasi. "Populasi adalah wilayah generalisasi yang terdiri atas obyek/subyek yang mempunyai kualitas dan karakteristik tertentu yang ditetapkan oleh peneliti untuk dipelajari dan kemudian ditarik kesimpulannya" (Sugiyono, 2012: 61). Populasi dalam penelitian ini adalah siswa kelas XI IPS SMA Negeri 1 Prambanan Klaten Tahun Ajaran 2016/2017 yang berjumlah 92 siswa. Adapun perinciannya adalah sebagai berikut:

\section{Tabel 1. Jumlah Populasi Penelitian}

\begin{tabular}{|l|c|}
\hline \multicolumn{1}{|c|}{ Kelas } & Jumlah Siswa \\
\hline XI IPS 1 & 31 \\
\hline XI IPS 2 & 30 \\
\hline XI IPS 3 & 31 \\
\hline Jumlah & 92 \\
\hline
\end{tabular}

\section{Teknik dan Instrumen Pengumpulan Data}

a. Teknik Pengumpulan Data

Dalam penelitian ini teknik pengumpulan data yang digunakan yaitu angket atau kuesioner, dokumentasi, dan wawancara. Angket atau kuesioner merupakan teknik pengumpulan data dimana 
partisipan/responden mengisi pertanyaan atau pernyataan kemudian setelah diisi dengan lengkap mengembalikan kepada peneliti (Sugiyono, 2015: 230). Jenis angket yang digunakan dalam penelitian ini adalah angket tertutup. Angket tertutup adalah angket yang telah dilengkapi dengan alternatif jawaban dan responden tinggal memilih salah satu jawaban pada alternatif jawaban yang sudah tersedia sesuai dengan keadan responden. Menurut Nana Syaodih S. (2012: 221) Studi dokumenter (dokumentasi) merupakan suatu teknik pengumpulan data dengan menghimpun dan menganalisis dokumen-dokumen, baik dokumen tertulis, gambar, maupun elektronik. Menurut Sugiyono, 2015: 194) wawancara digunakan sebagai teknik pengumpulan data untuk mengetahui hal-hal yang lebih mendalam mengenai responden. Jenis wawancara yang digunakan adalah wawancara terstruktur dan dilakukan melalui tatap muka (face to face). Dalam melakukan wawancara, pengumpul data telah menyiapkan instrumen sebagai pedoman penelitian berupa pertanyaan-pertanyaan tertulis yang alternatif jawabannya telah disediakan

b. Instrumen Penelitian

Instrumen Penelitian adalah sebuah alat bantu yang digunakan oleh peneliti untuk membantu dalam kegiatannya atau dalam penelitiannya sehingga kegiatan atau penelitian tersebut menjadi sistematis dan dipermudah olehnya (Suharsimi Arikunto, 2010: 101).

Instrumen yang digunakan dalam penelitian ini guna memperoleh data Motivasi Belajar $\left(\mathrm{X}_{1}\right)$, Minat Belajar $\left(\mathrm{X}_{2}\right)$, dan Perhatian Orang Tua $\left(\mathrm{X}_{3}\right)$ dalam lembar angket.

Angket yang digunakan adalah angket tertutup, yaitu angket yang telah dilengkapi dengan alternatif jawaban dan responden tinggal memilih salah satu jawaban pada alternatif jawaban yang sudah tersedia sesuai dengan keadan responden.

\section{Teknik Analisis Data}

Penelitian ini menggunakan teknik analisis data yang berupa uji prasyarat analisis yang meliputi uji linearitas dan uji multikolinearitas, serta uji hipotesis yang meliputi analisis regresi sederhana dan analisis regresi berganda.

\section{HASIL PENELITIAN DAN PEM- BAHASAN \\ Deskripsi Data Khusus}

a. Prestasi Belajar Akuntansi

Berdasarkan data Prestasi Belajar Akuntansi yang diperoleh dari niai ratarata Ujian Harian (UH), Ujian Tengah Semester (UTS), dan Ujian Akhir Semester (UAS) semester genap mata pelajaran akuntansi, diperoleh hasil skor tertinggi sebesar 87; skor terendah 37; dengan nilai Mean (M) sebesar 61.75; Median (Me) sebesar 56; Modus (Mo) sebesar 77; Standar Deviasi (SD) sebesar 14,130. Adapun Tabel Distribusi Frekuensi Data Variabel Prestasi Belajar Akuntansi dapat dilihat dari tabel berikut:

Tabel 2. Distribusi Frekuensi

Data Variabel

Prestasi Belajar Akuntansi

\begin{tabular}{|c|c|c|}
\hline No. & Interval & Frekuensi \\
\hline 1. & $37-43$ & 7 \\
\hline 2. & $44-50$ & 13 \\
\hline 3. & $51-57$ & 32 \\
\hline 4. & $58-64$ & 5 \\
\hline 5. & $65-71$ & 1 \\
\hline 6. & $72-78$ & 19 \\
\hline 7. & $79-85$ & 12 \\
\hline 8. & $86-92$ & 3 \\
\hline \multicolumn{2}{|c|}{ Jumlah } & 92 \\
\hline
\end{tabular}

Berdasarkan tabel distribusi frekuensi tersebut, dapat digambarkan histogram sebagai berikut: 


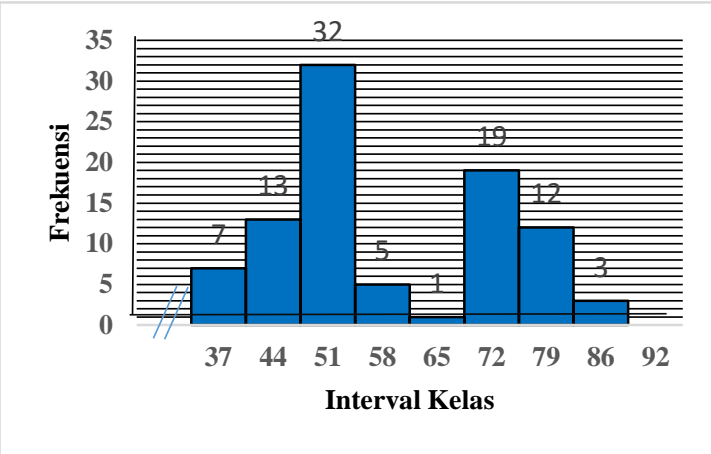

Gambar 1. Histogram

Distribusi

Frekuensi Prestasi

Belajar Akuntansi

Pengkategorian kecenderungan variabel Prestasi Belajar Akuntansi dapat dikategorikan menjadi tuntas dan belum tuntas. Kelompok tuntas apabila $\geq 75$, kelompok belum tuntas apabila <75. Berdasarkan data Prestasi Belajar Akuntansi dapat dibuat kategori kecenderungan sebagai berikut:

Tabel 3. Kategori

Kecenderungan

Prestasi Belajar

Akuntansi

\begin{tabular}{|c|c|c|c|c|}
\hline $\begin{array}{c}\text { N } \\
\text { o }\end{array}$ & $\begin{array}{c}\text { In- } \\
\text { ter- } \\
\text { val }\end{array}$ & F & $\%$ & $\begin{array}{c}\text { Katego- } \\
\text { ri }\end{array}$ \\
\hline 1 & $\geq 75$ & 61 & 66,30 & Tuntas \\
\hline 2 & $<75$ & 31 & 33,70 & $\begin{array}{c}\text { Belum } \\
\text { Tuntas }\end{array}$ \\
\hline \multicolumn{2}{|c|}{ Jumlah } & 92 & 100 & \\
\hline
\end{tabular}

Berdasarkan tabel 3 tersebut, dapat dibuat Pie Chart sebagai berikut:

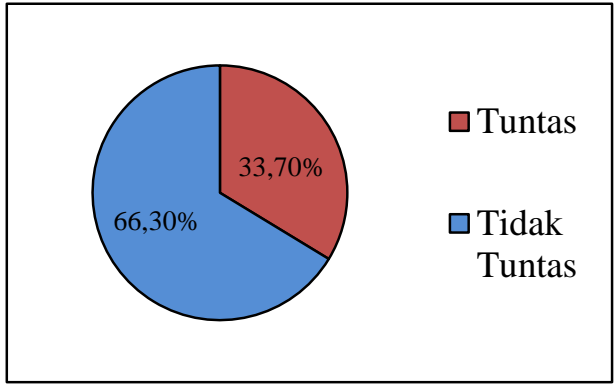

\section{Gambar 2. Pie Chart Variabel Prestasi Belajar Akuntansi}

Berdasarkan tabel 3 dan pie chart tersebut diketahui frekuensi variabel Prestasi Belajar Akuntansi pada kategori Tuntas sebanyak 31 siswa $(33,70 \%)$, pada kategori belum tuntas sebanyak 61 siswa $(66,30 \%)$.

b. Motivasi Belajar

Berdasarkan data Motivasi Belajar yang diperoleh dari angket Motivasi Belajar, variabel Motivasi Belajar memiliki skor tertinggi sebesar 70; skor terendah sebesar 30; dengan nilai Mean sebesar 45,05; Median sebesar 44,50; Modus sebesar 35; dan Standar deviasi sebesar 9,845. Adapun Tabel Distribusi Frekuensi Data Variabel Motivasi Belajar dapat dilihat dari tabel berikut:

Tabel 4. Distribusi Frekuensi Motivasi Belajar

\begin{tabular}{|c|c|c|}
\hline No. & Interval & F \\
\hline 1. & $29-34$ & 18 \\
\hline 2. & $35-40$ & 23 \\
\hline 3. & $41-46$ & 19 \\
\hline 4. & $47-52$ & 9 \\
\hline 5. & $53-58$ & 16 \\
\hline 6. & $59-64$ & 4 \\
\hline 7. & $65-70$ & 3 \\
\hline \multicolumn{2}{|c|}{ Jumlah } & 92 \\
\hline
\end{tabular}




\begin{tabular}{llr}
\multicolumn{2}{c}{ Berdasarkan tabel } & distribusi \\
frekuensi & tersebut, & dapat \\
digambarkan & histogram & sebagai \\
berikut: & &
\end{tabular}

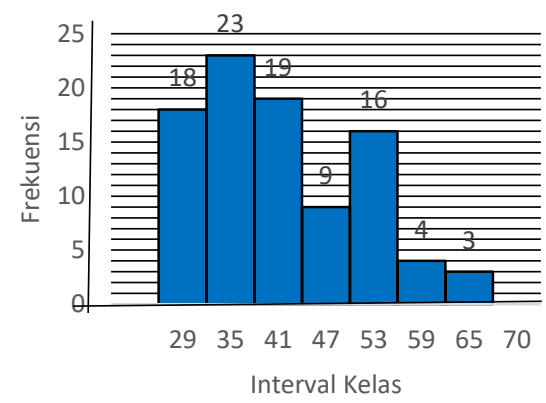

Gambar Histogram

3.

Distribusi

Frekuensi Motivasi

Belajar

Pengkategorian kecenderungan variabel Motivasi Belajar dapat dikategorikan menjadi sangat tinggi, tinggi, rendah dan sangat rendah (Djemari Mardapi, 2008: 123). Kelompok sangat tinggi apabila $x \geq 60,005$, kelompok tinggi apabila $50 \leq x<60,005$, kelompok rendah apabila $39,995 \leq \mathrm{x}<50$, kelompok sangat rendah apabila $x<39,995$, Berdasarkan data Motivasi Belajar dapat dibuat kategori kecenderungan sebagai berikut:

Tabel 5. Kecenderungan

Skor Variabel

Motivasi Belajar

\begin{tabular}{|c|c|c|c|}
\hline Interval & $\mathbf{F}$ & $\mathbf{\%}$ & $\begin{array}{c}\text { Kategor } \\
\mathbf{i}\end{array}$ \\
\hline $\mathrm{x} \geq 60,005$ & 5 & 5,43 & $\begin{array}{c}\text { Sangat } \\
\text { Tinggi }\end{array}$ \\
\hline $50 \leq \mathrm{x}<60,005$ & 26 & $\begin{array}{c}28,2 \\
6\end{array}$ & Tinggi \\
\hline $\begin{array}{c}39,995 \leq \mathrm{x}<5 \\
0\end{array}$ & 21 & $\begin{array}{c}22,8 \\
3\end{array}$ & Rendah \\
\hline $\mathrm{x}<39,995$ & 40 & $\begin{array}{c}43,4 \\
8\end{array}$ & $\begin{array}{c}\text { Sangat } \\
\text { Rendah }\end{array}$ \\
\hline Jumlah & 92 & 100 & \\
\hline
\end{tabular}

Berdasarkan tabel 5 tersebut, dapat dibuat Pie Chart sebagai berikut:

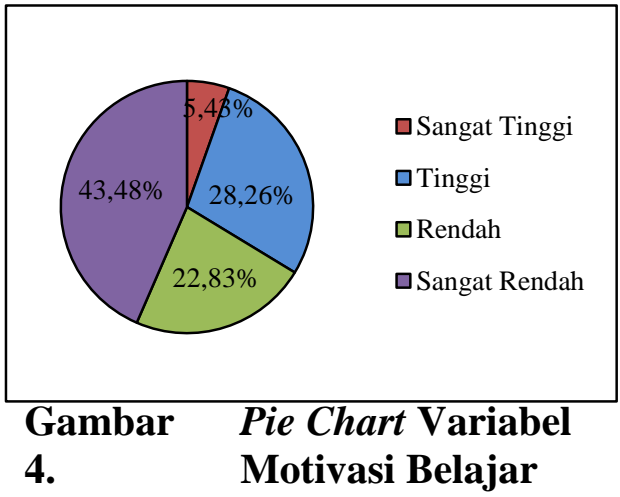

Berdasarkan tabel 5 dan pie chart tersebut diketahui frekuensi variabel Motivasi Belajar pada kategori sangat tinggi sebanyak 5 siswa $(5,43 \%)$, pada kategori tinggi sebanyak 26 siswa $(28,26 \%)$, dan pada kategori rendah sebanyak 21 siswa $(22,83 \%)$, kategori sangat rendah sebanyak 40 siswa $(43,48 \%)$.

c. Minat Belajar

Berdasarkan data Minat Belajar yang diperoleh dari angket Minat Belajar, variabel Minat Belajar memiliki skor tertinggi sebesar 59; skor terendah sebesar 34; dengan nilai Mean sebesar 44,92; Median sebesar 44,50; Modus sebesar 45; dan Standar deviasi sebesar 6,650. Adapun Tabel Distribusi Frekuensi Data Variabel Minat Belajar dapat dilihat dari tabel berikut:

Tabel 6. Distribusi Frekuensi Minat Belajar

\begin{tabular}{|c|c|c|}
\hline No. & Interval & F \\
\hline 1. & $34-37$ & 13 \\
\hline 2. & $38-41$ & 18 \\
\hline 3. & $42-45$ & 26 \\
\hline 4. & $46-49$ & 12 \\
\hline 5. & $50-53$ & 9 \\
\hline 6. & $54-57$ & 9 \\
\hline 7. & $58-61$ & 5 \\
\hline \multicolumn{2}{|c|}{ Jumlah } & 92 \\
\hline \multicolumn{2}{|c|}{ Berdasarkan tabel distribusi }
\end{tabular}
frekuensi tersebut, dapat digambarkan histogram sebagai berikut: 


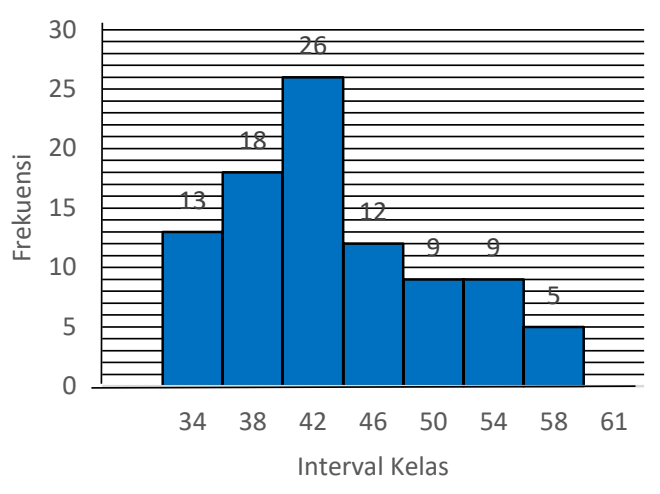

\section{Gambar 5.}

Pengkategorian kecenderungan variabel Minat Belajar dapat dikategorikan menjadi sangat tinggi, tinggi, rendah dan sangat rendah (Djemari Mardapi, 2008: 123). Kelompok sangat tinggi apabila $\mathrm{x} \geq 52,755$, kelompok tinggi apabila $46,5 \leq x<52,755$, kelompok rendah apabila 40,245 $\leq x<46,5$, kelompok sangat rendah apabila $\mathrm{x}<40,245$. Berdasarkan data Perhatian Orang Tua dapat dibuat kategori kecenderungan sebagai berikut:

Tabel 7. Kecenderungan Skor Minat Belajar

\begin{tabular}{|c|c|c|c|}
\hline Interval & $\mathbf{F}$ & \% & Kategori \\
\hline $\mathrm{x} \geq 87$ & 9 & 9,8 & $\begin{array}{c}\text { Sangat } \\
\text { tinggi }\end{array}$ \\
\hline $\begin{array}{c}72,5 \leq \mathrm{x}< \\
87\end{array}$ & 30 & $\begin{array}{c}32, \\
6\end{array}$ & Tinggi \\
\hline $\begin{array}{c}58 \leq \mathrm{x}<7 \\
2,5\end{array}$ & 44 & $\begin{array}{c}47, \\
8\end{array}$ & Rendah \\
\hline $\mathrm{x}<58$ & 9 & 9,8 & $\begin{array}{c}\text { Sangat } \\
\text { rendah }\end{array}$ \\
\hline Jumlah & 92 & $\begin{array}{c}10 \\
0\end{array}$ & \\
\hline
\end{tabular}

Berdasarkan tabel 7 tersebut, dapat dibuat Pie Chart sebagai berikut:

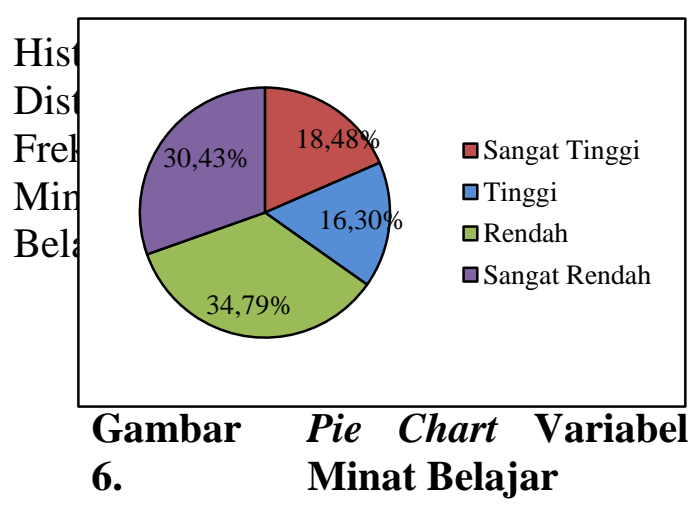

Berdasarkan tabel 7 dan Pie Chart tersebut diketahui frekuensi variabel Minat Belajar pada kategori sangat tinggi sebanyak 17 siswa $(18,48 \%)$, pada kategori tinggi sebanyak 15 siswa $(16,30 \%)$, dan pada kategori rendah sebanyak 32 siswa $(34,79 \%)$, kategori sangat rendah sebanyak 28 siswa $(30,43 \%)$.

d. Perhatian Orang Tua

Berdasarkan data Perhatian Orang Tua yang diperoleh dari angket Perhatian Orang Tua, variabel Perhatian Orang Tua memiliki skor tertinggi sebesar 62; skor terendah sebesar 24; dengan nilai Mean sebesar 50,93; Median sebesar 51; Modus sebesar 49; dan Standar deviasi sebesar 6,428. Adapun Tabel Distribusi Frekuensi Data Variabel Lingkungan Teman Sebaya dapat dilihat dari tabel berikut:

Tabel 8. Distribusi Frekuensi Perhatian Orang Tua

\begin{tabular}{|c|c|c|}
\hline No. & Interval & F \\
\hline 1. & $24-29$ & 1 \\
\hline 2. & $30-35$ & 0 \\
\hline 3. & $36-41$ & 5 \\
\hline 4. & $42-47$ & 19 \\
\hline 5. & $48-53$ & 33 \\
\hline 6. & $54-59$ & 26 \\
\hline 7. & $60-65$ & 8 \\
\hline \multicolumn{2}{|c|}{ Jumlah } & 92 \\
\hline
\end{tabular}




\begin{tabular}{llr}
\multicolumn{2}{c}{ Berdasarkan tabel } & distribusi \\
frekuensi & tersebut, & dapat \\
digambarkan & histogram & sebagai \\
berikut: & &
\end{tabular}

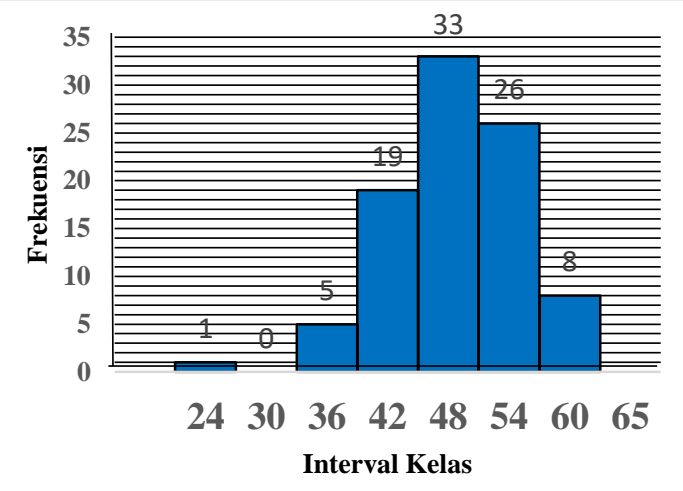

Gambar Histogram Distribusi 7. Frekuensi Perhatian Orang Tua

Pengkategorian kecenderungan variabel Perhatian Orang Tua dapat dikategorikan menjadi sangat tinggi, tinggi, rendah dan sangat rendah (Djemari Mardapi, 2008: 123). Kelompok sangat tinggi apabila $\mathrm{x} \geq 68$, kelompok tinggi apabila $63 \leq \mathrm{x}<68$, kelompok rendah apabila $57 \leq x<63$, kelompok sangat rendah apabila $\mathrm{x}<57$. Berdasarkan data Perhatian Orang Tua dapat dibuat kategori kecenderungan sebagai berikut:

Tabel 9. Kecenderungan Skor Perhatian Orang Tua

\begin{tabular}{|c|c|c|c|}
\hline Interval & $\mathbf{F}$ & $\%$ & Kategori \\
\hline $\mathrm{x} \geq 68$ & 0 & 0 & $\begin{array}{c}\text { Sangat } \\
\text { tinggi }\end{array}$ \\
\hline $63 \leq \mathrm{x}<68$ & 0 & 0 & Tinggi \\
\hline $57 \leq \mathrm{x}<63$ & 17 & 18,48 & Rendah \\
\hline $\mathrm{x}<57$ & 75 & 81,52 & $\begin{array}{c}\text { Sangat } \\
\text { rendah }\end{array}$ \\
\hline Jumlah & 92 & 100 & \\
Berdasarkan tabel 9 tersebut,
\end{tabular}
dapat dibuat Pie Chart sebagai berikut:

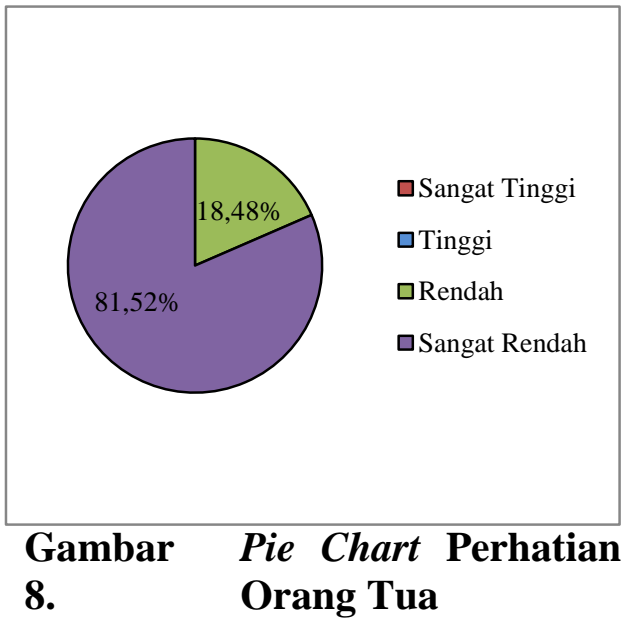

Berdasarkan tabel 9 dan Pie Chart tersebut diketahui frekuensi variabel Perhatian Orang Tua pada kategori sangat tinggi sebanyak 0 siswa (0\%), pada kategori tinggi sebanyak 0 siswa $(0 \%)$, dan pada kategori rendah sebanyak 17 siswa $(18,48 \%)$, kategori sangat rendah sebanyak 6 siswa $(81,52 \%)$.

\section{Uji Prasyarat Analisis}

a. Uji Linearitas

Tabel 10. Ringkasan Hasil Uji Linearitas

\begin{tabular}{|l|c|c|c|}
\hline Variabel & $\boldsymbol{D} \boldsymbol{f}$ & $\begin{array}{c}\text { Harga } \\
\text { F hitung }\end{array}$ & Ket. \\
\hline $\mathrm{X}_{1} \rightarrow \mathrm{Y}$ & $30 ; 60$ & 1,130 & Linear \\
\hline $\mathrm{X}_{2} \rightarrow \mathrm{Y}$ & $22 ; 68$ & 0,957 & Linear \\
\hline $\mathrm{X}_{3} \rightarrow \mathrm{Y}$ & $24 ; 66$ & 1,423 & Linear \\
\hline
\end{tabular}

Berdasarkan tabel 10 tersebut, semua variabel dinyatakan linear. 
b. Uji Multikolinearitas

\section{Tabel Ringkasan Hasil Uji 11. Multikolinearitas}

\begin{tabular}{|c|c|c|c|c|}
\hline $\begin{array}{l}\text { Vari- } \\
\text { abel }\end{array}$ & $\mathbf{X}_{1}$ & $\mathbf{X}_{2}$ & $\mathbf{X}_{\mathbf{3}}$ & $\begin{array}{c}\text { Ke- } \\
\text { sim- } \\
\text { pulan }\end{array}$ \\
\hline $\begin{array}{c}\text { Moti- } \\
\text { vasi } \\
\text { Bela- } \\
\text { jar } \\
\left(\mathrm{X}_{1}\right) \\
\end{array}$ & 1 & $\begin{array}{l}0,5 \\
48\end{array}$ & $\begin{array}{c}0,3 \\
94\end{array}$ & \multirow{3}{*}{$\begin{array}{c}\text { Tidak } \\
\text { terjadi } \\
\text { multi- } \\
\text { koli- } \\
\text { neari- } \\
\text { tas }\end{array}$} \\
\hline $\begin{array}{c}\text { Minat } \\
\text { Bela- } \\
\text { jar } \\
\left(\mathrm{X}_{2}\right)\end{array}$ & $\begin{array}{c}0,5 \\
48\end{array}$ & 1 & $\begin{array}{l}0,2 \\
57\end{array}$ & \\
\hline $\begin{array}{c}\text { Perha- } \\
\text { tian } \\
\text { Orang } \\
\text { Tua } \\
\left(\mathrm{X}_{3}\right)\end{array}$ & $\begin{array}{l}0,3 \\
94\end{array}$ & $\begin{array}{l}0,2 \\
57\end{array}$ & 1 & \\
\hline
\end{tabular}

Multikolinearitas jika nilai koefisien korelasi antar variabel bebas kurang dari 0,600. Berdasarkan table tersebut diketahui nilai interkorelasi antara variabel Motivasi Belajar dan Minat Belajar adalah 0,548; Motivasi Belajar dan Perhatian Orang Tua adalah 0,394; dan Minat Belajar dan Perhatian Orang Tua adalah 0,257. Hasil tersebut menunjukkan bahwa tidak ada multikolinearitas antarvariabel bebas karena nilai interkolerasi kurang dari 0,600.

\section{Uji Hipotesis}

a. Uji Hipotesis Pertama

Hasil analisis regresi sederhana menunjukkan bahwa koefisien korelasi antara $\mathrm{X}_{1}$ terhadap $\mathrm{Y}\left(\mathrm{r}_{\mathrm{x} 1 \mathrm{y}}\right)$ menunjukkan nilai sebesar 0,874 yang berarti bahwa Motivasi Belajar memiliki pengaruh yang positif terhadap Prestasi Belajar Akuntansi. Koefisien determinasi $\left(\mathrm{r}_{\mathrm{x} 1 \mathrm{y}}\right)$ sebesar 0,764 menunjukkan bahwa Motivasi Belajar mampu mempengaruhi perubahan Prestasi Belajar Akuntansi sebesar $76,4 \%$.
Persamaan garis regresi sederhana yang terbentuk adalah $\mathrm{Y}=$ 1,254X $\mathrm{X}_{1}+5,236$. Hasil analisis menunjukkan bahwa $r_{x 1 y}$ sebesar 0,$874 ; r^{2}$ x1y sebesar 0,764 ; dan $t_{\text {hitung }}$ lebih besar dari $t_{\text {tabel }}(17,062>$ 1,987), sehingga hipotesis pertama diterima. Kesimpulan dari uji hipotesis pertama adalah terdapat pengaruh positif Motivasi Belajar $\left(\mathrm{X}_{1}\right)$ terhadap Prestasi Belajar Akuntansi (Y) siswa kelas XI IPS SMA Negeri 1 Prambanan Klaten Tahun Ajaran 2016/2017.

b. Uji Hipotesis Kedua

Hasil analisis regresi sederhana menunjukkan bahwa koefisien korelasi antara $\mathrm{X}_{2}$ terhadap $\mathrm{Y}\left(\mathrm{r}_{\mathrm{x} 2 \mathrm{y}}\right)$ menunjukkan nilai sebesar 0,628 yang berarti bahwa Minat Belajar memiliki pengaruh yang positif terhadap Prestasi Belajar Akuntansi. Koefisien determinasi $\left(r^{2} \times 2 y\right)$ sebesar 0,394 menunjukkan bahwa Minat Belajar mampu mempengaruhi perubahan Prestasi Belajar Akuntansi sebesar 39,4\%. Persamaan garis regresi sederhana yang terbentuk adalah $\mathrm{Y}=1,334 \mathrm{X}_{2}$ $+1,837$. Hasil analisis menunjukkan bahwa $r_{x 2 y}$ sebesar 0,628; $r^{2}{ }_{x 2 y}$ sebesar 0,394; dan thitung lebih besar dari $t_{\text {tabel }}(7,649>1,987)$, sehingga hipotesis kedua diterima. Kesimpulan dari uji hipotesis kedua adalah terdapat pengaruh positif Minat Belajar $\left(\mathrm{X}_{2}\right)$ terhadap Prestasi Belajar Akuntansi (Y) siswa kelas XI IPS SMA Negeri 1 Prambanan Klaten Tahun Ajaran 2016/2017.

c. Uji Hipotesis Ketiga

Hasil analisis regresi sederhana menunjukkan bahwa koefisien korelasi antara $\mathrm{X}_{3}$ terhadap $\mathrm{Y}\left(\mathrm{r}_{\mathrm{x} 3 \mathrm{y}}\right)$ menunjukkan nilai sebesar 0,437 yang berarti bahwa Perhatian Orang Tua memiliki pengaruh yang 
positif terhadap Prestasi Belajar Akuntansi. Koefisien determinasi $\left(\mathrm{r}_{\mathrm{x} 3 \mathrm{y}}^{2}\right)$ sebesar 0,191 menunjukkan bahwa Perhatian Orang Tua mampu mempengaruhi perubahan Prestasi Belajar Akuntansi sebesar 19,1\%. Persamaan garis regresi sederhana yang terbentuk adalah $\mathrm{Y}=0,960 \mathrm{X}_{3}+12,835$. Hasil analisis menunjukkan bahwa $r_{x 3 y}$ sebesar 0,$437 ; r^{2} \times 3 y$ sebesar 0,191 ; dan $t_{\text {hitung }}$ lebih besar dari $\mathrm{t}_{\text {tabel }}(4,607>1,987)$, sehingga hipotesis ketiga diterima. Kesimpulan dari uji hipotesis ketiga adalah terdapat pengaruh positif Perhatian Orang Tua $\left(\mathrm{X}_{3}\right)$ terhadap Prestasi Belajar Akuntansi (Y) siswa kelas XI IPS SMA Negeri 1 Prambanan Klaten Tahun Ajaran 2016/2017.

\section{d. Uji Hipotesis Keempat}

Hasil analisis regresi ganda menunjukkan bahwa koefisien korelasi antara $\mathrm{X}_{1}, \mathrm{X}_{2}, \mathrm{X}_{3}$ secara bersama-sama terhadap $\mathrm{Y}$ menunjukkan nilai sebesar 0,896 yang berarti bahwa Motivasi Belajar, Minat Belajar, dan Perhatian Orang Tua secara bersama-sama memiliki pengaruh yang positif terhadap Prestasi Belajar Akuntansi. Koefisien determinasi sebesar 0,804 menunjukkan bahwa Motivasi Belajar, Minat Belajar, dan Perhatian Orang Tua secara bersama-sama mampu mempengaruhi perubahan Prestasi Belajar Akuntansi sebesar $80,4 \%$. Persamaan garis regresi sederhana yang terbentuk adalah $\mathrm{Y}=$ $1,036 X_{1}+0,439 X_{2}+0,218 X_{3}-$ 15,748. Hasil analisis menunjukkan bahwa $\mathrm{R}_{\mathrm{y}(1,2,3)} \quad$ sebesar 0,896; $\mathrm{R}_{\mathrm{y}(1,2,3)}^{2}$ sebesar 0,804; dan $\mathrm{F}_{\text {hitung }}$ lebih besar dari $F_{\text {tabel }}(120,095>$ 2,47), sehingga hipotesis keempat diterima. Kesimpulan dari uji hipotesis keempat adalah terdapat pengaruh positif Motivasi Belajar,
Minat Belajar, dan Perhatian Orang Tua secara bersama-sama terhadap Prestasi Belajar Akuntansi siswa kelas XI IPS SMA Negeri 1 Prambanan Klaten Tahun Ajaran 2016/2017.

\section{Sumbangan Efektif dan Sumbangan Relatif}

Tabel Sumbangan Relatif 12. dan Sumbangan Efektif

\begin{tabular}{|l|c|c|}
\hline $\begin{array}{c}\text { Variabel } \\
\text { Bebas }\end{array}$ & SR & SE \\
\hline $\begin{array}{l}\text { Motivasi } \\
\text { Belajar }\end{array}$ & $60,81 \%$ & $48,90 \%$ \\
\hline $\begin{array}{l}\text { Minat } \\
\text { Belajar }\end{array}$ & $25,25 \%$ & $20,22 \%$ \\
\hline $\begin{array}{l}\text { Perhatian } \\
\text { Orang Tua }\end{array}$ & $14,04 \%$ & $11,29 \%$ \\
\hline \multicolumn{1}{|c|}{ Jumlah } & $100 \%$ & $80,41 \%$ \\
\hline
\end{tabular}

Berdasarkan hasil analisis yang tercantum dalam tabel di atas dapat diketahui bahwa Motivasi Belajar memberikan sumbangan relatif sebesar 60,81\%, Minat Belajar memberikan sumbangan relatif sebesar 25,15\% dan Perhatian Orang Tua memberikan sumbangan relatif sebesar $14,04 \%$.

Sumbangan efektif yang diberikan oleh variabel Motivasi Belajar sebesar 48,90\%, Minat Belajar memberikan sumbangan efektif sebesar 20,22\% dan Perhatian Orang Tua memberikan sumbangan efektif sebesar $11,29 \%$. Total sumbangan efektif $80,41 \%$ yang berarti Motivasi Belajar, Minat Belajar dan Perhatian Orang Tua secara bersama-sama memberikan sumbangan efektif sebesar 80,41\% terhadap Prestasi Belajar Akuntansi sedangkan 19,59\% dari variabel lain yang tidak diteliti dalam penelitian ini. 


\section{SIMPULAN DAN SARAN \\ Simpulan}

a. Motivasi Belajar berpengaruh positif terhadap Prestasi Belajar Akuntansi Siswa Kelas XI IPS SMA Negeri 1 Prambanan Klaten Tahun Ajaran 2016/2017 yang dibuktikan dengan koefisien korelasi $r_{x 1 y}$ sebesar 0,874 ; koefisien determinasi $\mathrm{r}^{2}{ }_{\mathrm{x} 1 \mathrm{y}}$ sebesar 0,764 ; dan thitung sebesar 17,062 .

b. Minat Belajar berpengaruh positif terhadap Prestasi Belajar Akuntansi Siswa Kelas XI IPS SMA Negeri 1 Prambanan Klaten Tahun Ajaran 2016/2017 yang dibuktikan dengan koefisien korelasi $r_{x 2 y}$ sebesar 0,628; koefisien determinasi $\mathrm{r}^{2}{ }_{\mathrm{x} 2 \mathrm{y}}$ sebesar 0,394 ; dan thitung sebesar 7,649.

c. Perhatian Orang Tua berpengaruh positif terhadap Prestasi Belajar Akuntansi Siswa Kelas XI IPS SMA Negeri 1 Prambanan Klaten Tahun Ajaran 2016/2017 yang dibuktikan dengan koefisien korelasi $r_{x 3 y}$ sebesar 0,437; koefisien determinasi $\mathrm{r}^{2}{ }_{\mathrm{x} 3 \mathrm{y}}$ sebesar 0,191 ; dan thitung sebesar 4,607.

d. Motivasi Belajar, Minat Belajar, dan Perhatian Orang Tua secara bersamasama berpengaruh positif terhadap Prestasi Belajar Akuntansi Siswa Kelas XI IPS SMA Negeri 1 Prambanan Klaten Tahun Ajaran 2016/2017 yang ditunjukkan dengan koefisien korelasi $\mathrm{R}_{\mathrm{y}(1,2,3) \quad \text { sebesar } 0,896 \text {; koefisien }}$ determinasi $\mathrm{R}_{\mathrm{y}(1,2,3)}^{2}$ sebesar 0,804 ; dan Fhitung sebesar 120,095. Sumbangan relatif Motivasi Belajar $\left(\mathrm{X}_{1}\right)$ terhadap Prestasi Belajar Akuntansi (Y) sebesar 60,81\%; Sumbangan relatif Minat Belajar $\left(\mathrm{X}_{2}\right)$ terhadap Prestasi Belajar Akuntansi (Y) sebesar 25,15\%; dan sumbangan relatif Perhatian Orang Tua $\left(\mathrm{X}_{3}\right)$ terhadap Prestasi Belajar Akuntansi (Y) sebesar 14,04\%. Sumbangan efektif Motivasi Belajar $\left(\mathrm{X}_{1}\right)$ terhadap Prestasi Belajar Akuntansi (Y) sebesar 48,90\%; sumbangan efektif minat Belajar $\left(\mathrm{X}_{2}\right)$ terhadap Prestasi Belajar Akuntansi (Y) sebesar 20,22\% dan sumbangan efektif
Perhatian Orang Tua $\left(\mathrm{X}_{3}\right)$ terhadap Prestasi Belajar Akuntansi (Y) sebesar $11,29 \%$.

\section{Implikasi}

a. Telah terbukti bahwa terdapat pengaruh positif Motivasi Belajar terhadap Prestasi Belajar Akuntansi siswa kelas XI IPS SMA Negeri 1 Prambanan Klaten Tahun Ajaran 2016/2017. Hal ini menunjukkan Motivasi Belajar yang tinggi akan menyebabkan Prestasi Belajar Akuntansi menjadi tinggi dan sebaliknya, sehingga diperlukan upaya untuk meningkatkan Motivasi Belajar ke arah yang lebih baik untuk membantu meningkatkan Prestasi Belajar Akuntansi.

b. Telah terbukti bahwa terdapat pengaruh positif Minat Belajar terhadap Prestasi Belajar Akuntansi siswa kelas XI IPS SMA Negeri 1 Prambanan Klaten Tahun Ajaran 2016/2017. Hal ini menunjukkan Minat Belajar yang tinggi akan menyebabkan Prestasi Belajar Akuntansi menjadi tinggi dan sebaliknya, sehingga diperlukan upaya untuk meningkatkan Minat Belajar ke arah yang lebih baik untuk membantu meningkatkan Prestasi Belajar Akuntansi.

c. Telah terbukti bahwa terdapat pengaruh positif Perhatian Orang Tua terhadap Prestasi Belajar Akuntansi siswa kelas XI IPS SMA Negeri 1 Prambanan Klaten Tahun Ajaran 2016/2017. Hal ini menunjukkan Perhatian Orang Tua yang baik akan menyebabkan Prestasi Belajar Akuntansi menjadi tinggi dan sebaliknya, sehingga diperlukan upaya untuk meningkatkan Perhatian Orang Tua ke arah yang lebih baik untuk membantu meningkatkan Prestasi Belajar Akuntansi.

d. Telah terbukti bahwa terdapat pengaruh positif Motivasi Belajar, Minat Belajar dan Perhatian Orang Tua secara bersama-sama terhadap Prestasi Belajar Akuntansi siswa kelas XI IPS SMA 
Negeri 1 Prambanan Klaten Tahun Ajaran 2016/2017. Semakin tinggi Motivasi Belajar, semakin tinggi Minat Belajar dan semakin baik Perhatian Orang Tua siswa maka akan semakin tinggi pula Prestasi Belajar Akuntansi yang dicapai siswa, sehingga diperlukan upaya untuk meningkatkan Motivasi Belajar, Minat Belajar dan Perhatian Orang Tua agar siswa mencapai Prestasi Belajar Akuntansi yang tinggi.

\section{Saran}

a. Bagi Guru

Berdasarkan data yang diperoleh dari pengisian angket, pada variabel Motivasi Belajar, siswa belum dapat mempertahankan pendapatnya sehingga apabila jawaban teman berbeda dengan jawabannya maka siswa cenderung ragu dengan jawabannya. Pada variabel Minat Belajar, siswa tidak mencari buku lain diperpustakaan yang berhubungan dengan akuntansi selain buku wajib yang digunakan guru sehingga kemauan siswa dalam mempelajari akuntansi dengan baik dan untuk menambah informasi terkait akuntansi masih rendah. Pada variabel Perhatian Orang Tua, siswa merasa bahwa orang tua mereka terlalu memaksakan kehendaknya mengenai cara belajar siswa dirumah. Hal-hal tersebut bisa terjadi karena rendahnya Motivasi Belajar dan Minat Belajar, serta kurangnya Perhatian Orang Tua terhadap anaknya. Guru hendaknya dapat membangkitkan Motivasi Belajar dan Minat Belajar siswa, seperti menjelaskan kepada siswa tentang manfaat mempelajari akuntansi untuk meningkatkan Motivasi Belajar siswa dan menggunakan metode pembelajaran yang menarik dan bervariasi sehingga dapat membangkitkan Minat Belajar pada siswa. Hal tersebut merupakan salah satu cara yang dilakukan untuk meningkatkan Motivasi Belajar dan
Minat Belajar siswa sehingga lebih baik lagi. Sementara itu, hendaknya orang tua siswa tidak memaksakan kehendaknya mengenai cara belajar anaknya dirumah dikarenakan setiap individu mempunya cara belajar yang berbeda, sehingga akan lebih baik jika orang tua membebaskan anaknya dalam memilih cara belajar sesuai dengan yang diinginkan. Dalam meningkatkan Motivasi Belajar, Minat Belajar, dan Perhatian Orang Tua maka guru dan orang tua harus bersinergi dalam upaya meningkatkan Prestasi Belajar Akuntansi siswa.

b. Bagi Pihak Sekolah

Pada variabel Perhatian Orang Tua, siswa merasa perhatian yang didapatkan dari orang tuanya masih rendah sehingga belum memberikan dukungan yang maksimal terhadap kegiatan belajar siswa diluar sekolah, sehingga diharapkan sekolah dapat menjalin komunikasi dan bekerjasama dengan para orang tua siswa untuk bersinergi dalam upaya untuk meningkatkan prestasi belajar siswa. Salah satunya yaitu dengan mengadakan sharing atau rapat dengan para orang tua mengenai kendala-kendala yang dihadapi oleh siswa dalam mencapai prestasi belajar yang optimal.

\section{c. Bagi Penelitian Selanjutnya}

Penelitian ini memberikan informasi bahwa Motivasi Belajar, Minat Belajar dan Perhatian Orang Tua secara bersama-sama berpengaruh terhadap Prestasi Belajar Akuntansi. Sumbangan efektif yang diberikan adalah sebesar $80,41 \%$ Hal tersebut menunjukkan bahwa Prestasi Belajar Akuntansi tidak hanya dipengaruhi oleh tiga variabel yaitu Motivasi Belajar, Minat Belajar dan Perhatian Orang Tua namun masih terdapat $19,59 \%$ dipengaruhi oleh variabel-variabel lain yang tidak diteliti pada penelitian ini. Oleh karena itu, 
diharapkan dalam penelitian selanjutnya dapat ditemukan faktorfaktor lain yang dapat mempengaruhi Prestasi Belajar Akuntansi.

DAFTAR PUSTAKA

Djemari Mardapi. (2008). Teknik Penyusunan Instrumen Tes dan Nontes. Yogyakarta: Mitra Cendikia Press.

Nana Syaodih Sukmadinata. (2012), Metode Penlelitian Pendidikan. Bandung: Rosdakarya.

Sugiyono. (2015). Metode Penelitian Manajemen. Bandung: Alfabeta.

(2012). Statistika untuk Penelitian. Bandung: Alfabeta.

Suharsimi Arikunto. (2010). Prosedur Penelitian Suatu Pendekatan Praktik. Jakarta: Rineka Cipta. 